\title{
Effectiveness of Yoga as the Public Health Intervention Module in the Management of Diabetes and Diabetes Associated Dementia in South East Asia: A Narrative Review
}

\author{
Parul Balia Navneet Kaur ${ }^{a, b} \quad$ Abha Tiwari $^{a}$ Sridhar Bammidia Vivek Podder \\ Chandra Devi $^{a}$ Saurabh Kumar ${ }^{a}$ Madhava Sai Sivapuram ${ }^{d}$ Abdul Ghani ${ }^{\mathrm{C}}$ \\ Shweta Modgila Neeru Malik ${ }^{f}$ Akshay Anand ${ }^{a}$ \\ ${ }^{a}$ Neuroscience Research Lab, Department of Neurology, Postgraduate Institute of Medical Education and Research \\ (PGIMER), Chandigarh, India; ${ }^{b}$ Department of Physical Education, Panjab University, Chandigarh, India; ' Department \\ of General Medicine, Kamineni Institute of Medical Sciences, Narketpally, India; ${ }^{\mathrm{d}}$ Department of General Medicine, \\ Dr. Pinnamaneni Siddhartha Institute of Medical Sciences and Research Foundation, Chinna Avutapalli, India; \\ e Department of Histopathology, Postgraduate Institute of Medical Education and Research (PGIMER), Chandigarh, \\ India; ${ }^{\mathrm{f}}$ Dev Samaj College of Education, Chandigarh, India
}

\section{Keywords}

Dementia - Diabetes · Public health · Yoga · Physical activity

\begin{abstract}
Background: Diabetes mellitus (DM) is widely spread in South Asian (ASEAN) and Indian sub-continent. The increasing healthcare costs of DM can be prevented in the developing world by improved public healthcare interventions. Modifiable risk factors of DM like sedentary lifestyle, obesity, and stressful conditions are associated with its progression; however, the epidemiological data collected by Public Institutions are limited. Summary: A review of published literature describing geographic distribution of DM and associated dementia in South Asian region, particularly India, was conducted with the purpose of assessing the feasibility and challenges associated with the Yoga-based risk reduction. PubMed and Google Scholar databases were searched for DM and dementia-related articles by using a combination of keywords: Diabetes, Diabetes related Dementia Southeast
\end{abstract}

\section{KARGER}

(c) 2020 S. Karger AG, Basel

karger@karger.com

www.karger.com/ned
Asia, Pre-diabetes, Yoga, lifestyle modification, Dementia and Exercise. The epidemiological data generated from these diseases have not prompted to any major public health policies. Yoga can be a cost-effective intervention for the prevention of Type 2 DM (T2DM) and its associated cognitive decline when detected early. If nationwide intervention of Yoga is brought about by the state, its integration in health care will become more meaningful and acceptable. Key Message: Studies suggest that Yoga and change in lifestyle can modify the health risks associated with T2DM and associated dementia if it is mainstreamed with the public health initiative of Ayushman Bharat scheme. @ 2020 S. Karger AG, Basel

\section{Introduction}

Diabetes mellitus (DM) is a metabolic disorder spreading at an alarming rate in India, which is considered as the future "Diabetic capital". An expected 66.8 million 
population is faced with this condition [1]. Type $2 \mathrm{DM}$ (T2DM) progression is characterized by insulin resistance resulting in increased level of blood glucose [2]. It may also develop due to genetic and non-genetic (age, obesity, sedentary lifestyle, and stress) risk factors [3] that are modifiable. The epidemic of diabetes is also related with various complications like dementia, Alzheimer's disease $(\mathrm{AD})$, vascular dementia, heart attack, stroke, peripheral neuropathy, diabetic nephropathy, cerebrovascular diseases, diabetic retinopathy, diabetic foot, and so on. Hyperactivation of hypothalamic-pituitary-adrenal axis with increased cortisol production has also been noted in DM [4-6] but not studied adequately. Increased cortisol production is linked with stress, which is one of the main risk factors associated with dementia [4]. In this review, we have discussed how progression of T2DM increases the vulnerability toward dementia and whether intervention methods like Yoga practice can strengthen the existing public health policies for these twin diseases.

It is believed that through change in lifestyle and dietary habits, it is possible to control glucose levels (and dementia). Yoga with its eightfold path (Yama, Niyama, Asana, Pranayama, Pratyahara, Dharana, Dhyana, and Samadhi) helps in lifestyle paradigm shift and improves the overall well-being of an individual $[3,7]$, providing compelling evidence that high-risk individuals may be prevented from the development of T2DM and associated dementia by modification in the lifestyle. It has also been shown that the prevalence of DM decreases by $58 \%$ in such cases [3]. The literature review and policy framework that promote Yoga as a possible intervention for DM (and its related comorbidities) are discussed here in order to provide insights for future researchers and policy makers.

\section{Methodology}

This narrative review presents the current literature in the field of DM and diabetes-associated dementia along with the evidence of Yoga in the management of both in South East Asia (SEA). The following databases were included in the literature search: PubMed and Google Scholar. Literature search included the following keywords: Diabetes, Southeast Asia, Pre-diabetes, Yoga, lifestyle modification, Dementia and Exercise, Diabetes induced Dementia. We excluded the following study designs: case reports and case series papers. The systematic reviews, meta-analysis, randomized controlled trials (RCT), non-RCTs, and longitudinal and cross-sectional studies that assessed incidence and prevalence of DM and associated dementia in SEA and India were included. This also included the risk factors of DM and dementia besides the public health intervention programs like exercise and Yoga. These were presented as varying from the Western public health delivery model.

\section{Prevalence of Diabetes}

The World Health Organization (WHO) has estimated 422 million adults who are battling with DM, and this number is estimated to double by 2030 . The T2DM constitutes almost $85 \%$ of the cases [8]. According to WHO "Global report on DM", SEA has shown a rapid increase in both regions (i.e., rural and urban). The WHO estimated that 96 million people have DM in SEA, out of which $90 \%$ have T2DM. According to $\mathrm{WHO}$, this has increased from 17 million (1980) to 96 million (2014).

India is ranked second behind China in the global incidence of DM. The maximum incidence of DM is seen in Mauritius (14.8\%), where majority of Indians are settled. Currently, 73 million individuals are affected in India. This constitutes $>8.8 \%$ of adult population [9] of which $49 \%$ are females and $51 \%$ are males. Sixty-three percent prevalence has been reported in rural population, whereas $37 \%$ in urban population [10]. The cities affected with DM show variable percentage of prevalence as shown in Table 1 [10]. According to World Diabetes Foundation report, people living with T2DM in India is expected to increase by $10 \%$ (123 million) in the year 2035. Many studies have also emphasized that Asian Indians have a greater risk of DM and have younger age of onset and lower body mass index (BMI) risk threshold in comparison to other Asian populations, whether they lived in India or in any other foreign country. This makes Indians the most vulnerable to DM and associated.

\section{Prevalence of Dementia}

According to a prediction by WHO, by 2050, approximately 2.1 billion of the world population individuals will soon attain an age above 60 years [11]. It is estimated that the total number of individuals living with dementia has witnessed more than twofold increase from 20.2 million (1990) to 43.8 million (2016). It is also estimated that the prevalence of dementia will approximate 100 million by the year 2050 [12]. The prevalence of dementia in SEA countries and rest of the world are mentioned in Table 2. However, none of these estimates have recorded the age of onset or association with dementia, thus neglecting an important comorbidity.

The prevalence rate of dementia (Table 2) in India differs widely according to the different regions. The cause behind this variation in prevalence rate is the variability in the selection of approaches and methodologies, screening equipments, inclusion criteria, influence of various ethnic, cultural and environmental factors besides its association with increase in diabetes [13]. However, in none of these studies, the relation of diabetes with dementia was comprehensively examined, leaving a void in our understanding of the threat diabetes will pose for the incidence of dementia.

\section{Relationship between Diabetes and Dementia}

Cognitive dysfunction manifests at a later period of life $(>60$ years). It is a complication of DM, predisposing diabetic patients to develop dementia making them susceptible to $\mathrm{AD}$ [14]. DM and dementia, the 2 prevailing diseases among the elderly, were studied by different investigators (Table 3 ). As mentioned, T2DM has a positive relationship with dementia, and hence, the declining cognitive function may render the elderly disabled [15-17]. Early-onset DM-related development of dementia remains unexplored in epidemiological studies, although some studies have reported that T2DM has an association with cognitive impairment (memory and executive both), vascular dementia, and AD along with other 
Table 1. Prevalence of T1DM and T2DM in SEA countries and India $[9,10]$

\begin{tabular}{|c|c|c|c|c|}
\hline \multicolumn{5}{|c|}{ Prevalence of T1DM and T2DM in SEA countries } \\
\hline \multicolumn{2}{|l|}{$\mathrm{DM}$} & country & year 2000 & year 2030 \\
\hline \multicolumn{2}{|c|}{ India (\% DM in total population) } & Thailand & $1,536,000$ & $2,739,000$ \\
\hline \multicolumn{2}{|c|}{$8.8 \%$ (adult) } & Sri Lanka & 653,000 & $1,537,000$ \\
\hline Urban & 63 & Maldives & 6,000 & 25,000 \\
\hline Rural & 37 & Indonesia & $8,426,000$ & $21,257,000$ \\
\hline \multicolumn{2}{|c|}{ Akhtar and Dhillon [10], 2017} & India & $31,705,000$ & $79,441,000$ \\
\hline & Democratic People Republic of Korea & 367,000 & 635,000 \\
\hline \multicolumn{2}{|c|}{$\begin{array}{l}\text { Gender-wise distribution, \% } \\
\text { Male }\end{array}$} & Bhutan & 35,000 & 109,000 \\
\hline \multicolumn{2}{|c|}{$\begin{array}{c}\text { Female } \\
\text { Akhtar and Dhillon [10], } 2017\end{array}$} & Bangladesh & $3,196,000$ & $11,140,000$ \\
\hline country & $\begin{array}{l}\text { age-standardized } \\
\text { prevalence, } \%\end{array}$ & regions & \multicolumn{2}{|c|}{ percentage } \\
\hline Mauritius & 14.8 & Goa & \multicolumn{2}{|c|}{17.7} \\
\hline India & 9.1 & Pondicherry & \multicolumn{2}{|c|}{16.9} \\
\hline Sri Lanka & 7.6 & Tamil Nadu & \multicolumn{2}{|c|}{16.1} \\
\hline Bangladesh & 6.3 & Kerala & \multicolumn{2}{|c|}{13.6} \\
\hline Bhutan & 5.8 & Chandigarh & \multicolumn{2}{|c|}{11.5} \\
\hline Nepal & 4.9 & Bihar & \multicolumn{2}{|c|}{$<3.5$} \\
\hline Maldives & 4.8 & Madhya Pradesh & \multicolumn{2}{|c|}{$<3.5$} \\
\hline \multicolumn{2}{|c|}{ Diabetes in SEA region: an update } & Odisha & \multicolumn{2}{|c|}{$\begin{array}{l}<3.5 \\
<3.5\end{array}$} \\
\hline
\end{tabular}

DM, diabetes mellitus; T2DM, type 2 DM; WHO, World Health Organization; SEA, South East Asia.

Table 2. Prevalence of dementia in India, SEA, and the world $[12,13]$

\begin{tabular}{|c|c|c|c|c|c|}
\hline \multicolumn{6}{|c|}{ Prevalence of dementia } \\
\hline \multicolumn{2}{|c|}{$\begin{array}{l}\text { prevalence of dementia in } \\
\text { India [13] }\end{array}$} & \multicolumn{2}{|c|}{$\begin{array}{l}\text { prevalence of dementia } \\
\text { in SEA countries [12] }\end{array}$} & \multicolumn{2}{|c|}{$\begin{array}{l}\text { global prevalence of } \\
\text { dementia [12] }\end{array}$} \\
\hline regions & percentage & countries & 2016 (millions) & regions & 2016 (millions) \\
\hline South India & 3.6 & India & 2.9 & America & 7.9 \\
\hline North India & $0.84-3.39$ & Indonesia & 1.1 & Australia & 0.2 \\
\hline Western India & $2.44-4.1$ & Vietnam & 0.6 & Africa & 4.1 \\
\hline \multirow[t]{5}{*}{ East India } & $0.8-1.28$ & Thailand & 0.5 & Asia & 19.2 \\
\hline & & Bangladesh & 0.4 & Europe & 9.0 \\
\hline & & Philippines & 0.3 & & \\
\hline & & Sri Lanka & 0.1 & & \\
\hline & & Nepal & 0.06 & & \\
\hline
\end{tabular}

SEA, South East Asia. 
Table 3. Longitudinal studies deciphering the association between DM and cognitive decline [15-17]

\begin{tabular}{|c|c|c|c|c|c|c|c|}
\hline \multirow[t]{2}{*}{ Study } & \multirow[t]{2}{*}{ Type of study } & \multirow[t]{2}{*}{$\begin{array}{l}\text { Sample } \\
\text { size }\end{array}$} & \multirow[t]{2}{*}{$\begin{array}{l}\text { Age, } \\
\text { years }\end{array}$} & \multirow[t]{2}{*}{ Aims of the study } & \multirow{2}{*}{$\begin{array}{l}\text { Baseline } \\
\text { cognitive decline }\end{array}$} & \multirow{2}{*}{$\begin{array}{l}\text { Follow-up } \\
\text { (duration in years) } \\
\text { cognitive decline }\end{array}$} & \multirow[t]{2}{*}{$\begin{array}{l}\text { Outcome of } \\
\text { the study }\end{array}$} \\
\hline & & & & & & & \\
\hline $\begin{array}{l}\text { Zheng et al. } \\
{[15], 2018}\end{array}$ & $\begin{array}{l}\text { Longitudinal } \\
\text { study (2005-2015) }\end{array}$ & 5,189 & $65.6 \pm 94$ & $\begin{array}{l}\text { Association between } \\
\text { HBA1c, diabetes, } \\
\text { and cognitive } \\
\text { decline }\end{array}$ & $9.4 \pm 3.3$ & $4.9 \pm 1.5$ & $\begin{array}{l}\text { Study shows } \\
\text { increased rate of } \\
\text { cognitiveproblems } \\
\text { with diabetes }\end{array}$ \\
\hline $\begin{array}{l}\text { Hassing et al. } \\
{[16], 2004}\end{array}$ & $\begin{array}{l}\text { Longitudinal } \\
\text { study (1991-1998) }\end{array}$ & 274 & $83.52 \pm 33$ & $\begin{array}{l}\text { To examine } \\
\text { the cognitive } \\
\text { ability affected } \\
\text { by diabetes }\end{array}$ & $27.7 \pm 2.3$ & $16.9 \pm 2.3$ & $\begin{array}{l}\text { This study suggests that } \\
\text { T2D is associated } \\
\text { with increased risk } \\
\text { of cognitive impairment } \\
\text { in older adults }\end{array}$ \\
\hline $\begin{array}{l}\text { Gregg et al. } \\
{[17], 2000}\end{array}$ & $\begin{array}{l}\text { Prospective cohort } \\
\text { study (1986-1992) }\end{array}$ & 682 & $71.8 \pm 5.0$ & $\begin{array}{l}\text { Investigation the } \\
\text { risk of dementia } \\
\text { in patients with } \\
\text { diabetes }\end{array}$ & $1.10(086-1.40)$ & $1.04(0.76-1.41)$ & $\begin{array}{l}\text { Female diabetic } \\
\text { patient has more } \\
\text { risk }(57-114 \%) \\
\text { for neurocognitive de- } \\
\text { cline than } \\
\text { non-diabetic patients }\end{array}$ \\
\hline
\end{tabular}

T2D, type 2 diabetes; DM, diabetes mellitus; HbA1c, glycated hemoglobin.

factors like hypertension, dyslipidemia, and apolipoprotein [18]. $\mathrm{DM}$, as a risk factor for dementia, was postulated [19] when it was demonstrated that age increases the susceptibility of diabetes leading to dementia [20]. A study by Solanki et al. [21] reported that $48 \%$ of DM patients had characteristics similar to dementia. Positive correlation between DM and dementia was further reported in another study where association of apolipoprotein E (APOE) genotype was also indicated [22]. In another study, Khattar et al. [23] found cognitive decline in DM patients proving the link between DM and dementia. Imbalance of insulin and carbohydrate metabolism has been implicated in the progression of $\mathrm{AD}$ as the study showed neuroprotective role of glycemic control in T2DM [24]. In a large prospective study, Logroscino et al. [25] reported that women with T2DM showed very poor cognition compared to non-diabetic individuals. The study also reported that women on oral hypoglycemic medications for T2DM showed similar cognitive decline to non-diabetic individuals. Further studies have shown that among the oral pharmacological hypoglycemic treatments of DM, only long-term use of metformin therapy on DM patients has shown some protective effect on cognitive functions such as executive function, verbal learning and working memory $[26,27]$. The long-term intake of metformin has various side effects on diabetes patients, such as gastrointestinal, weight loss, lactic acidosis, and decreased vitamin B12 levels. It is also contraindicated in kidney and hepatic insufficiency diseases [28]. These studies emphasize the need to diagnose or detect pre-diabetes or undiagnosed DM, and when diagnosed, appropriate non-pharmacological interventions can be advised, to prevent Dementia at the earlier stage. This calls for mass-level public health initiatives for general wellness of population.

\section{Studies of Different Regions of India}

Non-obese Asian Indian males suffering from T2DM, recruited from North India region, have shown high plasma glucagon correlated with fatty liver disease. The glycemic index of patients with non-alcoholic fatty liver disease was found to be higher than T2DM patients without non-alcoholic fatty liver disease [29]. Recently, a survey conducted on North Indian population revealed that DM and pre-diabetes were extremely prevalent among adults [30]. A cross-sectional study was performed to estimate the DM occurrence in rural areas of Mandur and Goa. It was found to be $10.3 \%$. The factors which were found to be associated significantly on bivariate analysis included triglyceride levels, high serum cholesterol, age, occupation, family history of disease, family income, smoking, obesity, and hypertension. These factors are independently associated variables for DM and dementia as suggested by multiple logistic regression analysis [31].

A study done in North East India industrial community showed that incidence of DM was associated with increasing age, family history, and lack of physical activity. Therefore, timely detection and treatment are key to its management [32].

\section{Rural and Urban India Trends of DM}

The views of urban Indians regarding management or treatment and self-care are essential in evolving healthcare structure where pluralistic approaches like allopathic and non-allopathic paradigms are acceptable. The researchers have proposed an Integrative Medicine model incorporating both traditional and modern medical approaches. The data analysis from a study showed that participants selectively involved in building healthcare plans and personalized sickness conditions facilitate physical, social, and psychological needs as these emphasize the socio-communal experience of DM. This prosocial development about DM in India is helpful for patients and for providing psychological relief [33].

The Phase 1 Indian Council of Medical Research-India Diabetes study was conducted with participants in 4 different states and union territories in India. This included Tamil Nadu, Maharashtra, Jharkhand, and Chandigarh. The physical activity index was 


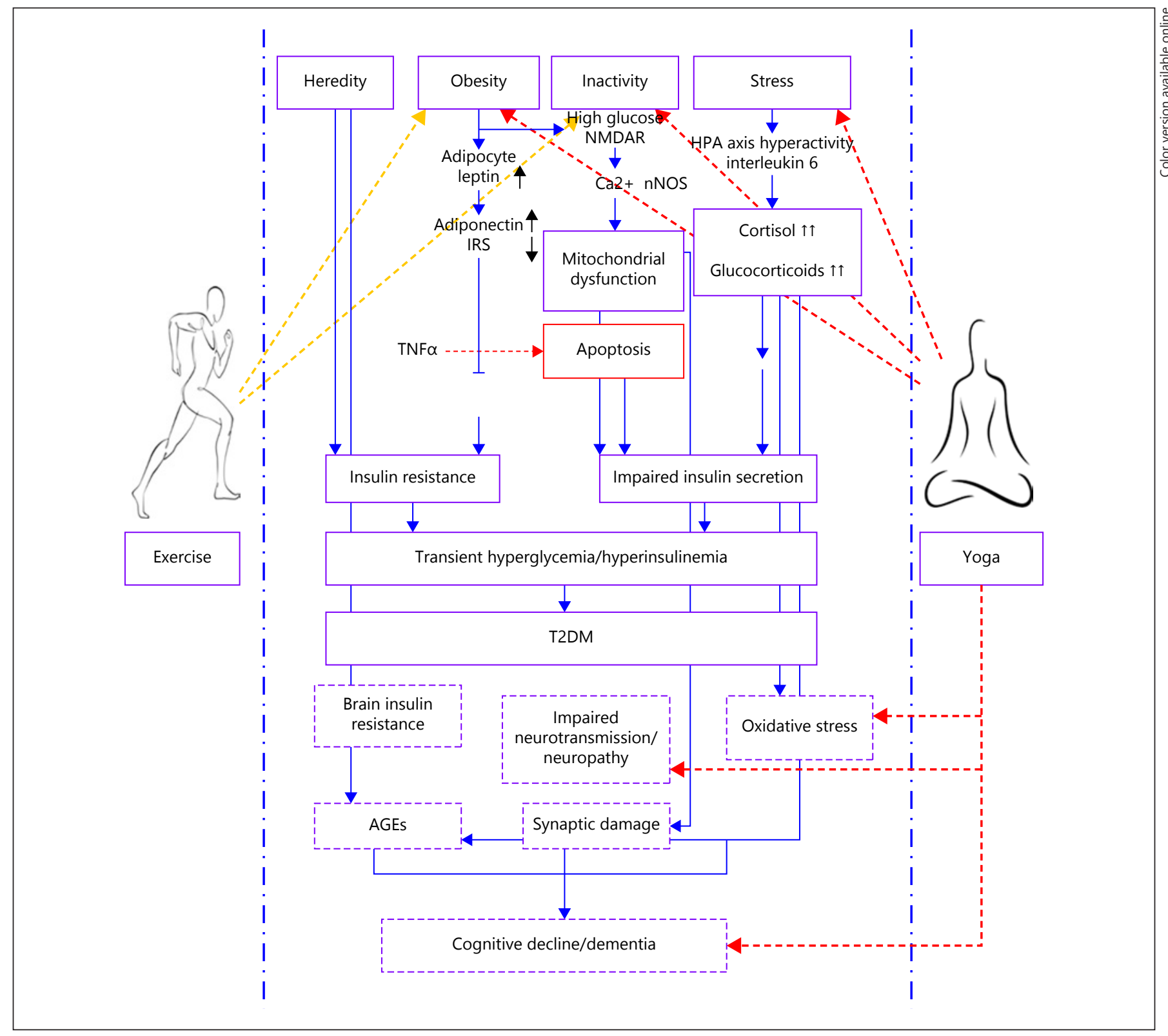

Fig. 1. Diabetes as a complex disorder associated with several factors leading to cognitive decline. The yellow lines represent the effect of exercise on obesity and inactivity, which in turn acts on impaired glucose secretion and insulin resistance to regulate DM. The red line represents the effect of Yoga on obesity, stress, impaired neurotransmission, and oxidative stress, thus further regu-

analyzed by Global Physical Activity Questionnaire on 14,227 participants aged $\geq 20$ years (urban $-4,173$; rural $-10,054$ ). The data showed very low percentage, that is, only $10 \%$ of individuals engage in physical activity and the remaining are inactive [34]. In another study of Indian Council of Medical Research-India Diabetes, the glycemic control, with self-reported DM among subjects, was analyzed by estimating glycated hemoglobin (HbAlc). Out of lating DM; it also prevents further deterioration of dementia. HPA, hypothalamic-pituitary-adrenalin; T2DM, type 2 diabetes mellitus; AGE, advanced glycation end product; N-methyl-d-aspartate; nNOS, neuronal nitric oxide synthases; IRS, insulin receptor substrate-1; TNFa, tumor necrosis factor- $\alpha$.

14,277 individuals, there were 480 subjects with self-reported DM that included 254 urban and 226 rural localities [35].

\section{Risk Factors Associated with Diabetes and Dementia}

In the postmodern scenario, there is an increase in tendency for the development of T2DM and dementia in SEA population due to risk factors illustrated in Figure 1 [36]. The major risk 
factors linked with T2DM are family history of DM and the candidate genes, besides growing age and obesity. Moreover, the environmental risk factors, lack of physical activity, excess alcohol intake, irregular sleeping patterns, and so on increase the chances for the development of T2DM $[37,38]$. Likewise, in the case of dementia, the genetic factors play a major role in its development along with growing age and gender $[39,40]$, and so on. Some of the risk factors are common for both T2DM and dementia and represent an underlying link between these 2 diseases.

\section{Age}

It is widely believed that middle and older age group individuals are at greater risk of developing T2DM. The age group between 45 and 64 years has been found to be the most affected group; however, early onset of T2DM is now beginning to be seen during the first decade of life [41]. Among Asian Indians, the early onset of T2DM was found to correlate with adverse outcomes of poor glycemic control [42]. The comparative analysis of early and late onset of T2DM has shown worsening of glycemic index, lipid control, and risk of retinopathy in younger diabetics as compared to older diabetic individuals [43], but similar studies on its association and co-prevalence with dementia are lacking. Progressive age is known as one of the major risk factors for dementia as the number of cases of dementia is growing among elderly population [44]. In elderly, there are numerous cognitive factors that contribute toward various pathologies related with $\mathrm{AD}$ and dementia [45]. AD affects 1-3\% of people from 60 to 64 years of age, $3-12 \%$ of people from age 70 to 80 years in western countries, and this proportion rises to $25-35 \%$ for people $>85$ years of age [46]. Furthermore, the parental history of dementia and APOE4 allele, along with growing age, further advances the risk of $\mathrm{AD}$ and dementia [47]. HbA1c, used as a diagnostic marker for T2DM, has also been found to be associated with cognitive impairment and dementia [48]. Studies have also suggested association of higher level of HbAlc with worse cognition among younger individuals while reversing the effect in very old ages [49].

\section{Alcohol Consumption}

A meta-analysis showed that there is $30 \%$ reduction of T2DM risk among individuals who have moderate alcohol $(\leq 6 \mathrm{~g} /$ day alcohol) consumption as compared to high alcohol consuming individuals (i.e., $\geq 48 \mathrm{~g} /$ day) [50]. The specific types of alcoholic beverage can also be an important factor for understanding the risk of T2DM. A study showed that limited wine consumption could be related with decreased risk of T2DM as compared to beer or spirit, suggesting that moderate consumption of alcohol might be beneficial in preventing development of T2DM [51]; however, none of these studies are prospective in nature and thus cannot be extrapolated for public health policies. In contrast, the use of excess alcohol can lead to a permanent structural and functional brain damage and which can become more severe with additional vitamin deficiencies like vitamin B1 [29, 52]. Alcohol-related cognition impairment is of 2 types: alcoholrelated dementia and Wernicke-Korsakoff syndrome. Visuospatial memory and executive functioning are affected in both the cases [29]. Contrary to this, an interesting 4-year follow-up study suggested that lower risk of $\mathrm{AD}$ was not associated with liquor, beer intake, but it was confined in individuals without
APOE epsilon-4 allele [31]. Furthermore, the different level of alcohol consumption manifests variability in cognitive outcomes [29].

\section{Effects of Smoking}

There are contradictory studies describing smoking as a risk factor for AD and dementia; some of these have reported smoking as a risk factor for dementia [53], while others found no correlation between the both $[54,55]$. Smoking is also known to affect other risk factors associated with dementia-like cardiovascular diseases $[56,57]$. In addition, the interaction of smoking with hereditary factors, viz. APOE, further enhances the chances for the development of dementia [58]. However, a report revealed that smokers with defective APOE e4 allele had negligible chances of dementia in comparison with the non-carrier smokers who are at a twofold risk of dementia and AD [59]. Smoking, when taken into account with age, enhances the risk for dementia in comparison with nonsmokers. However, the relation of historical smoking with dementia remains unknown [60].

\section{Body Mass Index}

Obese people are at a higher risk for developing T2DM, dementia, and $\mathrm{AD}$ [61-63]. BMI and dementia exhibit a U-shaped relationship [61]. Contrasting relationship has been seen with BMI, dementia, and AD. Obese people (BMI $>30)$ of 50 years of age are at higher risk of dementia than people with normal BMI, but a steady weight loss (annual $1 \mathrm{~kg} / \mathrm{m}^{2}$ ) in older people was found to be associated with $35 \%$ increased risk of AD [61]. Furthermore, studies in relationship between DM, dementia, and BMI $[62,64]$ are tabulated in Table 4.

\section{Gender}

Biocultural models are widely used to understand how social pathways define biological consequences. In India, this is the first study of T2DM women that explored bicultural perspective. Using this model, authors analyzed, in a set of 280 females without diabetes and those with T2DM women for health, social roles, biological correlations, and their interrelationships that prevail between diabetes, social role attainment, psychological stress, and biochemical variables assessing blood sugar control, immune stress, and generalized inflammation. One of the unchangeable risk factors for dementia was gender and growing age, which further reflects that women are more prone for the development of $\mathrm{AD}$ in comparison with men. The levels of blood sugar and $\mathrm{HbA} 1 \mathrm{c}$ have shown poor management in women. This is due to changing immune stress that often accompanies uncontrolled blood sugar [65]. Furthermore, studies with $\mathrm{AD}$, vascular dementia, and gender are listed in Table $4[66,67]$.

\section{Diet}

In an Indian study that was designed as population-based cross-sectional survey (NFHS-3, 2005-2006), population of all states of India was surveyed to determine the rate of occurrence of DM associated with dietary factors listed in Table 4, which showed diet is another modifiable risk factor that is involved in risk for DM and can be exploited for prevention-related studies. However, the intake should be in an established relationship with clinical measures for outreaching the maximum benefits [68, 69]. Furthermore, the presence of aluminum in drinking water and deficiency of vitamins (Vitamin B6, B12, E, and C) in the food increases the risk related with dementia $[70,71]$. 
Table 4. Risk factors for DM and dementia $[62,64,66,67,70,71]$

\begin{tabular}{|c|c|c|c|c|}
\hline Study & Type of study & Sample size & Aim of the study & Outcomes \\
\hline $\begin{array}{l}\text { BMI } \\
\text { Anstey et al. } \\
{[62], 2011}\end{array}$ & Meta-analysis & 71,529 & $\begin{array}{l}\text { Aim to synthesize data } \\
\text { between BMI and dementia } \\
\text { in middle age and late life }\end{array}$ & $\begin{array}{l}\text { U-shaped relationship between BMI and dementia. } 35 \% \\
\text { increased risk for AD in middle age ( } 40-59 \text { years); } 33 \% \\
\text { greater risk for vascular dementia in late-life ( } \geq 60 \text { years), } \\
\text { and } 26 \% \text { greater risk for developing any type of dementia }\end{array}$ \\
\hline $\begin{array}{l}\text { Bays et al. } \\
{[64], 2007}\end{array}$ & $\begin{array}{l}\text { Nation-wide US } \\
\text { cross-sectional study }\end{array}$ & 211,097 & $\begin{array}{l}\text { To find any association between } \\
\text { BMI and prevalence of DM }\end{array}$ & $\begin{array}{l}\text { Increased BMI showed a significant increase in } \\
\text { association with DM }\end{array}$ \\
\hline $\begin{array}{l}\text { Gender } \\
\text { Andersen et al. } \\
{[67], 1999}\end{array}$ & $\begin{array}{l}\text { Prospective } \\
\text { cohort study }\end{array}$ & $\begin{array}{l}528 \text { incident } \\
\text { cases of } \\
\text { dementia }\end{array}$ & $\begin{array}{l}\text { Incidence of dementia among } \\
\text { genders }\end{array}$ & $\begin{array}{l}\text { With increase in age, women are at more risk compared } \\
\text { to men but in vascular dementia there are no gender } \\
\text { differences }\end{array}$ \\
\hline $\begin{array}{l}\text { Wang et al. } \\
{[66], 2012}\end{array}$ & $\begin{array}{l}\text { Population-based } \\
\text { cohort study }\end{array}$ & 615,529 & $\begin{array}{l}\text { Association between } \\
\text { diabetes and risk of AD }\end{array}$ & $\begin{array}{l}\text { Diabetic men showed that an incident density of } A D \text { was } \\
0.82 \text { per } 1,000 \text { and for diabetic women it was } 1.15 \text { per } \\
1,000 \text {, a higher hazard ratio compared to men }\end{array}$ \\
\hline
\end{tabular}

Diet

Agrawal et al. National wide 198,754

[68], $2012 \quad$ cross-sectional study
To examine the effect of diet on prevalence of diabetes
Fish consumption has been reported to be inversely proportional to the diabetes prevention, whereas intake of fruits, pulses, and beans could help in prevention. However, taking milk or curd, eggs, vegetables, other factors such as television watching, alcohol consumption, or smoking do not create significant effect

Legumes intake was directly related to reduced risk of DM in women, but the opposite is found in men although in men the association is non-significant

DM, diabetes mellitus; AD, Alzheimer's disease; BMI, body mass index.

\section{Common Genes of Dementia, AD, and DM}

Several studies have shown the link of DM and dementia (AD). These disorders are amyloidosis and are featured by fibrillary aggregation in pancreases (amylin aggregation) and brain ( $\beta$-amyloid aggregation) [72]. Increased risk of dementia and $\mathrm{AD}$ in $\mathrm{DM}$ subjects suggests the interaction of some factors that play a role in both the disorders. APOE association has been found with dementia, metabolic disorders, and DM [72, 73]. Other genes like App, CEPBP, PARP1, PARK2, CXCR4, MT-CO2, CCR5, PIK3CD, and IGFIR have also been known to be involved in the cross-talk [73].

\section{Lack of Longitudinal Studies in Southeast Asia and \\ Indian Sub-Continent}

Both dementia and DM are age-associated disorders with increased incidence in older age. In this context, longitudinal studies with long follow-up of populations are required in order to understand the progression and relationship between these 2 intertwined disorders. Most of the longitudinal studies have been undertaken by China and USA with no matching studies from Indian population, making it difficult to allocate resources to predict comorbidities and manage rising health costs.

\section{Current Therapies and Clinical Trials}

There is a great need to develop preventive, curative, and cost-effective measures for DM and related dementia. Several drugs like memantine, donepezil, tacrine, rivastigmine, and galantamine have been approved and widely used for dementia and its associated disorders. Memantine inhibits glutamate activity and the other 4 are cholinesterase inhibitors. But these drugs only provide temporary relief by modifying the neuronal activities [74]. The improvements may not be significant and a number of side effects can be observed in the $\mathrm{AD}$ subjects $[33,74]$. Similarly, the drugs for diabetes like metformin, sulfonylureas, and meglitinides, along with insulin, provide only symptomatic relief and glycemic control, but the permanent treatment is still to be discovered $[34,75]$. 
Table 5. Failed clinical trials of anti-diabetic and anti-dementia drugs disease management by lifestyle modifications and integrative approaches [76-84]

\begin{tabular}{|c|c|c|c|c|}
\hline $\begin{array}{l}\text { Sr. } \\
\text { No. }\end{array}$ & Drug, year & $\begin{array}{l}\text { Termination } \\
\text { phase }\end{array}$ & Reason & Country \\
\hline 1 & $\begin{array}{l}\text { Enhanced care transition, } \\
\text { standard care transition }(2016)\end{array}$ & NA & $\begin{array}{l}\text { Due to funding problems, slow } \\
\text { recruitment and PI location change }\end{array}$ & Canada, Ontario \\
\hline 2 & $\begin{array}{l}\text { Insulin detemir, insulin NPH, } \\
\text { diet/exercise (2017) }\end{array}$ & Phase 3 & Very slow recruitment rate & $\begin{array}{l}\text { India, Argentina, Brazil, Croatia, Egypt, Germany, Greece, } \\
\text { Hungary, Israel, Italy, Republic of Korea, Lebanon, Malaysia, } \\
\text { Mexico, Morocco, Poland, Portugal, Russian Federation, } \\
\text { Serbia, South Africa, Spain, Taiwan, Turkey, United States }\end{array}$ \\
\hline 3 & Bifeprunox, placebo (2008) & Phase 3 & Slow enrollment & Czech Republic, Estonia, Israel, Poland, United States \\
\hline 4 & $\begin{array}{l}\text { Inhaled human insulin, } \\
\text { insulin aspart (2008) }\end{array}$ & Phase 3 & $\begin{array}{l}\text { An analysis concluded that fast-acting } \\
\text { inhaled insulin in the form it is known } \\
\text { today, is unlikely to offer significant } \\
\text { clinical or convenience benefits over } \\
\text { injections of modern insulin with pen } \\
\text { devices }\end{array}$ & $\begin{array}{l}\text { India, Argentina, Romania, Slovakia, Taiwan, Thailand, } \\
\text { Turkey }\end{array}$ \\
\hline 5 & $\begin{array}{l}\text { Rimonabant, glimepiride, } \\
\text { etformin (2009) }\end{array}$ & Phase 3 & $\begin{array}{l}\text { Company decision taken considering } \\
\text { demands by certain national health } \\
\text { authorities }\end{array}$ & $\begin{array}{l}\text { India, Chile, Denmark, Finland, Hungary, Italy, } \\
\text { Republic of Korea,, Mexico, Puerto Rico, Romania, } \\
\text { Russian Federation, Spain, Sweden, United States }\end{array}$ \\
\hline 6 & $\begin{array}{l}\text { Megestrol acetate, } \\
\text { placebo (2007) }\end{array}$ & Phases 2, 3 & $\begin{array}{l}2010 \text { Due to difficulties in recruiting the } \\
\text { patients following the inclusion criteria }\end{array}$ & Spain \\
\hline 7 & Aliskiren, placebo (2014) & Phase 3 & Lack of benefit and safety concern & $\begin{array}{l}\text { India, Argentina, Austria, Belgium, Brazil, Canada, China, } \\
\text { Colombia, Czech Republic, Denmark, Finland, France, } \\
\text { Germany, Greece, Guatemala, Hungary, Italy, Japan, Republic } \\
\text { of Korea, Lithuania, The Netherlands, Norway, Peru, } \\
\text { Portugal, Puerto Rico, Singapore, Slovakia, South Africa, } \\
\text { Spain, Sweden, Switzerland, Taiwan, Thailand, Turkey, } \\
\text { United Kingdom, United States, Venezuela }\end{array}$ \\
\hline 8 & $\begin{array}{l}\text { Pioglitazone, rosiglitazone, } \\
\text { placebo, dietary supplement: } \\
\text { vitamin D, placebo (2011) }\end{array}$ & Phase 4 & $\begin{array}{l}\text { FDA has placed the } \\
\text { trial on full clinical hold }\end{array}$ & $\begin{array}{l}\text { India, Argentina, Canada, Chile, Colombia, Czech Republic, } \\
\text { Denmark, Finland, Germany, Italy, Latvia, Mexico, The } \\
\text { Netherlands, Norway, Pakistan, Peru, Philippines, Romania, } \\
\text { Russian Federation, Slovakia, South Africa, Sweden, Thailand, } \\
\text { United Kingdom, United States }\end{array}$ \\
\hline 9 & $\begin{array}{l}\text { Tesaglitazar, metformin } \\
(2006)\end{array}$ & Phase 3 & $\begin{array}{l}\text { The development program } \\
\text { has been terminated }\end{array}$ & $\begin{array}{l}\text { India, Australia, Canada, Finland, Germany, Italy, Malaysia, } \\
\text { Philippines, Singapore, } \\
\text { Sweden, United Kingdom }\end{array}$ \\
\hline
\end{tabular}

There have been repeated efforts to discover anti-diabetic drugs, ranging from synthetic analogs, stem cells to herbal medicine, all of which have failed to rescue the disease despite huge investments (Table 5) [76-84]. Preventive medicine provides a health promotion pathway that is cost effective and accommodates wide range of evidence-based interventions ranging from Yoga, Tai chi, exercise, sports, and so on to meditation.

\section{Prevention of Dementia}

Livingston et al. [85] evaluated the population attributable fraction (PAF) of dementia. The PAF is defined as the reduction percentage of new cases over a period of given time if a risk factor is eliminated. The following were the modifiable risk factors of dementia: education (either none or primary school only) for the age group $<18$ years; hypertension, obesity, hearing loss for the age group 4565 years; smoking, depression, physical inactivity, social isolation, and diabetes in the age group of $>65$ years. The PAF estimates were calculated and reported as highest with hearing loss (23.0\%) in 45-65 age group, followed by less education (19.1\%) among $<18$ years age group and obesity $(2.0 \%)$ in the age group $45-65$ years [85]. A prospective population cohort study by Tari et al. [86] on cardiorespiratory fitness (CRF) and the associated risk of dementia mortality revealed that the population with highly fit CRF or improvement from unfit CRF to fit CRF showed a reduction of $30-40 \%$ in mortality and $40-50 \%$ reduction 
in incidence related to dementia. In comparison to unfit, the fit CRF individuals showed a delay of 2 years in the dementia onset and increase of life span by $2-3$ years [86].

\section{Disease Management by Lifestyle Modifications and} Integrative Approaches

External life events, for example, environmental factors, act as pivot in driving the disease pathogenesis. Chronic exposure to various environmental stressors adversely impacts human physiology by molecular alterations in the biological pathways, and this also influences the response to therapy. DM, being a major public health challenge and a heterogeneous disease, calls for better understanding of its pathogenesis, clinical manifestation, comorbidities, and future complications particularly dementia. Despite the heterogeneity of pathogenesis, DM is characterized by insulin resistance or relative insulin deficiency in the presence of hyperglycemia and represented with internal glycemic index parameters like $\mathrm{HbAlc}$, fasting blood sugar, and so on [87]. Several observational studies from high-income countries have found environmental effects influencing T2DM. Cortisol and cytokines released in response to the environmental stressors accelerate the development and progression of chronic diseases like DM [88]. Meeting the patient requirements need consideration of both internal molecular alterations and the external factors that influence health and disease. Several controlled trials have reported that short-term Yoga training programs reduce stress, improve mood, and reduce catecholamineand cortisollevels and blood pressure in both healthy and adult diabetic populations (Fig. 1). Several genomic studies on dementia caregivers and healthy adults have found that Yoga induces beneficial epigenetic changes in regulatory pathways of inflammation, oxidative stress, and insulin secretion [89].

$\mathrm{DM}$ is a complex multifactorial metabolic disorder. The sedentary lifestyle conditions lead to an increase in obesity and visceral fat resulting in hyperleptinemia and impaired adiponectin assimilation. Stress causes hyperactivation of the hypothalamic-pituitary-adrenalin axis, triggering oversecretion of cortisol. The upregulated glucocorticoids and resulting insulin resistance cause the upregulation of interleukins, which may lead to cell death. This results in the impaired insulin secretion. A transient hypoglycemia-insulin resistance-hyperinsulinemia causes a trigger for advanced glycation end products that are responsible for the metabolic syndrome.

In the postmodern scenario, with increase in lifestyle disorders, the pharmacological efforts have not yielded much promising results and lead to the re-emergence of alternative therapies [90]. Although physical exercise has been documented for weight management and lifestyle modification, Yoga scores high based on an overall wellbeing and whole-body treatment. It has been shown to act on mind-body level and successful in combating the metabolic disorder (Fig. 2).

The study carried out by Klarod et al. [91] was undertaken to understand the effects of exercise on prediabetic men. They reported that 3-week exercise training, when practised at moderate altitude, causes increased biological antioxidant activity of plasma without altering the fasting plasmaglucose. Another study analyzed the effect of 3-week uphill and downhill walking on glucose metabolism and level of lipids among prediabetics. It was reported that after uphill walking, the level of glucose tolerance, triglycerides, and total cholesterol improved significantly. They also emphasized that, depending on individual preferences, both types of exercises were useful for the prevention of T2DM. Moreover, Baker et al. [92] also revealed that 6 months of aerobic exercise improved executive function, CRF, and insulin sensitivity in adults with impaired glucose tolerance. They also suggested that in glucose-intolerant adults, the aerobic exercises showed enhanced effects on cognition. A significant relationship between physical activity as well as aerobic exercise and the levels of brain-derived neurotropic factor has also been reported in patients with $\mathrm{AD}$.

Three months of Yoga intervention on 123 T2DM patients has shown reduced BMI, level of malondialdehyde, and glycemic control. Oxidative stress was also found to be regulated through Yoga intervention, which was ascribed to the elevated level of glutathione and vitamin C (Fig. 1).

The intervention of Yoga in Parkinson's disease patients has also shown positive results and improved quality of life. The depression scores were also found to have improved in those patients [93]. In addition, Yoga also has been shown to have positive effect on memory [94], attention, and verbal fluency of aged population [95]. Moreover, the impact of silver Yoga on aged population with dementia has shown promising results on mental health, which includes decrease in behavioral and depressive behaviors [96]. Thus, these studies, which report positive results, suggest that it could be used as a promising tool for various cognition-related disorders [97].

While obesity, hyperlipidemia, and stress are the risk factors for the development of diabetes and dementia, none of the drugs directly modify these risk factors as effectively as Yoga and exercise in a cost-effective manner. Several studies have even compared the role of endurance exercise and Yoga in managing T2DM, suggesting it to be more effective over exercise [98]. Yoga has been shown to 


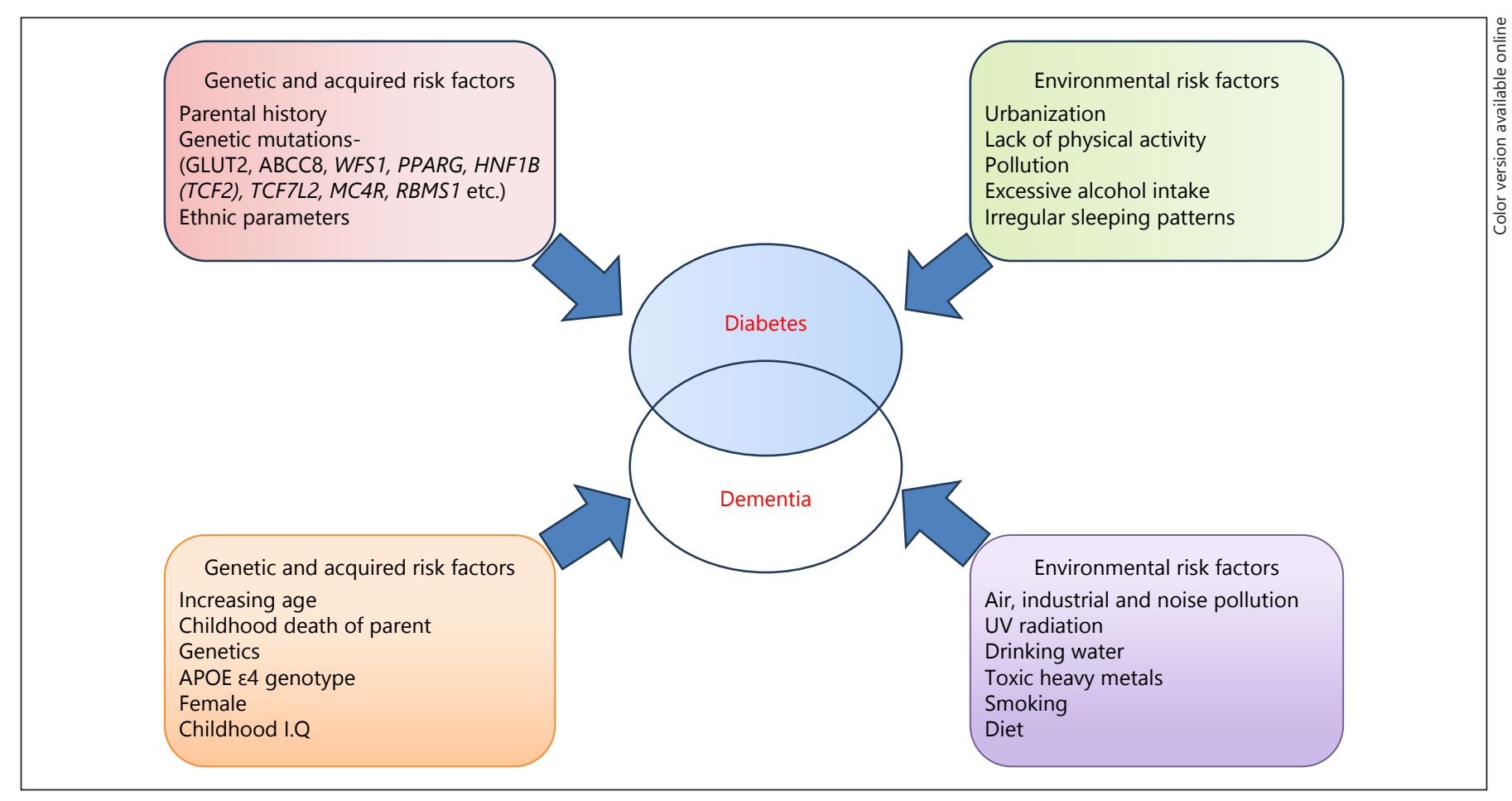

Fig. 2. Risk factors and genetic loci associated with diabetes and dementia.

not only alleviate anxiety and stress [99] but also obesity [100] and associated oxidative stress [101-103], thereby regulating diabetes-induced cognitive decline [104]. Similarly, exercise also controls obesity and alters the associated insulin signaling pathway that modulates insulin resistance responsible for the progression of T2DM. The effect of exercise on stress and the associated neurotransmission may be optimal, but the intermittent hypoxia caused due to various Yogic techniques and its possible effect on mitochondrial function are emerging as the predominant pathway for rescue of impaired insulin secretion and function [98]. The meta-analysis has shown better glycemic control in T2DM patients with Yoga as an intervention when compared to physical exercise [98]. In the Yoga-based lifestyle change program, significant reduction of glycemic index (fasting blood sugar, $\mathrm{HbAlc}$ ), insulin resistance, BMI, and lipid profile has been reported. The significant reduction was also found in psychological parameters such as anxiety and depression leading to improvement in quality of life [105]. Yoga as intervention in case-control studies and RCTs has showed statistically significant results in the reduction of blood glucose levels, as shown in Table 6. This significant decrease in blood glucose levels helps to control T2DM effectively along with the medication treatment [106-110].
A study carried out on rural population of Gujarat showed mixed response of subjects about traditional healing. While some found it beneficial, others reported that healers are not effective. In this study, authors suggested that association between faith healers and medical practitioners may perhaps reduce the burden of mental illness. The study was undertaken to understand the efficiency of faith-based adaptations on psychological parameters like depression and anxiety [111]. Likewise, an exploratory study carried out on terminal cancer subjects analyzed the impact of storytelling approach to increase a sense of connectedness and intimacy. The study showed a small and significant enhancement on spiritual wellbeing after intercessory prayers [112].

\section{Global Preventive Initiatives}

The burden of DM and related dementia on global public health needs to be resolved. National and international initiatives taken up by the government, community organizations, and health systems through different schemes, programs, efficacy research trials, media, schools, workshops, and policies can implement some preventive and cost-effective measures to reduce the burgeoning cases of DM and dementia as well as the awareness among people. Several RCTs have shown efficacy in 
Table 6. Yoga for the treatment of T2DM [106-110]

\begin{tabular}{|c|c|c|c|c|c|c|}
\hline $\begin{array}{l}\text { Study and } \\
\text { year }\end{array}$ & $\begin{array}{l}\text { Type of } \\
\text { the study }\end{array}$ & Sample size & Controls & Intervention & Weeks & Primary outcomes \\
\hline $\begin{array}{l}\text { Mondal } \\
\text { et al. [106], } \\
2018\end{array}$ & $\begin{array}{l}\text { Prospective } \\
\text { case-control } \\
\text { study }\end{array}$ & $\begin{array}{l}20 \mathrm{~T} 2 \mathrm{DM}(10 \text { yogic } \\
\text { intervention } \\
\text { and }+10 \text { controls })\end{array}$ & TAU & $\begin{array}{l}\text { Yogic intervention: } \\
\text { suryanamaskara; } 8 \text { asanas; } \\
\text { two kriyas and pranamaya }\end{array}$ & 12 & $\begin{array}{l}\text { Statistically significant decrease in FBG, } \\
\text { PPBG, and cholesterol levels }\end{array}$ \\
\hline $\begin{array}{l}\text { Sreedevi } \\
\text { et al. [107], } \\
2017\end{array}$ & RCT & $\begin{array}{l}124 \text { T2DM ( } 41 \text { yogic } \\
\text { intervention+ } 42 \\
\text { peer intervention } \\
+41 \text { control) }\end{array}$ & TAU & $\begin{array}{l}\text { Yogic intervention: } \\
\text { suryanamaskara; deep } \\
\text { relaxation muscle technique; } \\
\text { sanas; pranayama }\end{array}$ & 12 & $\begin{array}{l}\text { Trend of improving blood glucose levels } \\
\text { (FBG, PPBG, HbA1C); statistically } \\
\text { significant diastolic blood pressure }\end{array}$ \\
\hline $\begin{array}{l}\text { McDermott } \\
\text { et al. [108], } \\
2014\end{array}$ & $\mathrm{RCT}$ & $\begin{array}{l}41 \mathrm{~T} 2 \mathrm{DM}(21 \text { yogic } \\
\text { intervention and } \\
20 \text { walking control) }\end{array}$ & Walking & $\begin{array}{l}\text { Yogic intervention: } \\
\text { pranayama; loosening } \\
\text { exercise; standing asana; } \\
\text { supine asana; prone asana, } \\
\text { sitting asana, relaxation }\end{array}$ & 8 & $\begin{array}{l}\text { Significant decrease in weight, BMI, } \\
\text { and waist circumference that are risk } \\
\text { factors of diabetes }\end{array}$ \\
\hline $\begin{array}{l}\text { Singh } \\
\text { et al. [109], } \\
2019\end{array}$ & RCT & $\begin{array}{l}37 \text { T2DM ( } 22 \text { yogic } \\
\text { intervention and } \\
15 \text { were on waitlist) }\end{array}$ & TAU & $\begin{array}{l}\text { Yogic intervention: loosening } \\
\text { exercises; suryanamaskara; } \\
\text { asanas; relaxation }\end{array}$ & 12 & $\begin{array}{l}\text { Statistically significant decrease in } \mathrm{HbAlc} \text {, } \\
\text { mean plasma glucose, and cholesterol } \\
\text { levels in intervention group }\end{array}$ \\
\hline $\begin{array}{l}\text { Nagarathna } \\
\text { et al. [110], } \\
2012\end{array}$ & RCT & $\begin{array}{l}277 \text { T2DM ( } 141 \text { were } \\
\text { on yogic intervention } \\
\text { and } 136 \text { were } \\
\text { on exercise) }\end{array}$ & $\begin{array}{l}\text { Exercises on } \\
\text { standing position; } \\
\text { supine position; } \\
\text { rest and lectures }\end{array}$ & $\begin{array}{l}\text { Yogic intervention: } \\
\text { breathing exercise; } \\
\text { shithlikarana vyayama; } \\
\text { asanas; bandhas and } \\
\text { kriyas; pranayama; } \\
\text { meditation and lectures }\end{array}$ & 36 & $\begin{array}{l}\text { Statistically significant reduction in FBG, } \\
\text { LDL and medication requirement in } \\
\text { statistical significant increase in HDL } \\
\text { in yogic intervention group; also } \\
\text { HbA1C, PPBG, total cholesterol, } \\
\text { triglycerides, and VLDL decrease in both } \\
\text { groups but better effect in yogic group }\end{array}$ \\
\hline
\end{tabular}

T2DM, type II diabetes mellitus; RCT, randomized controlled trial; TAU, treatment as usual; FBG, fasting blood glucose; PPBG, postprandial blood glucose; HbA1c, glycated hemoglobin; BMI, body mass index; LDL, low-density lipoprotein; HDL, high-density lipoprotein; VLDL, very low-density lipoprotein.

reduction of diabetic incidence by structured modification in lifestyle leading to weight loss. Diabetes Prevention Program (DPP) is one such research trial of United States (US) - National Institute of Health for US population. The emphasis on caloric reduction and increase in physical activity in one group of DPP has remarkably shown $58 \%$ reduction in diabetic incidence over 4 years across male and females, races and ethnicities, and proved metformin (second group) as safe and effective for diabetes, as also briefly discussed earlier. In 2010, a panel of Centers for Disease Control and Prevention and an international group took action toward weight management and primary prevention of T2DM, through various "immediate" and "strategic" actions, together with research in different populations across certain countries [113]. Immediate and strategic actions proposed by health care includes primary measures, evaluation of a uniform diagnostic criterion, screening, diagnosis, risk status, financial support for prevention programs, and promotion of research. Public health system involved in supporting intervention delivery, implementing National DPP and delivering it to convenient sites, identifying policies, insurances, and incentives for sustainability of prevention pro- grams, and improving school, workplaces, or community sites to support a healthy lifestyle along with promoting research. More information about Centers for Disease Control and Prevention can be obtained from the site https://www.cdc.gov. Furthermore, financial incentives are provided to healthcare providers and organizations to provide high-quality care to healthcare purchasers. The US Centers for Medicare and Medicaid Services in USA is involved in such activities. US National Committee on Quality Assurance's Healthcare Effectiveness Data and Information Set is involved in the assessment of risk factors and diabetes development. Likewise, National Institutes of Health-funded Studies to Treat or Prevent Pediatric Type 2 Diabetes study showed decreased prevalence of overweight and obesity in a school-based intervention.

China is one among the Asian countries that is at greater risk for developing DM. It bears a huge burden of DM; hence, several researchers in China have developed an intervention program that is useful for high-risk individuals. A major intervention study (diet and Exercise) was conducted in China on individuals with impaired glucose tolerance and followed up for 6 years. It was found that by using lifestyle intervention tools, that is, 
diet and exercise, the incidence of conversion from prediabetes to diabetes was significantly reduced [114]. In a follow-up study of the same group after 20 years, it showed fewer occurrences (43\%) of diabetes in comparison with control group $[3,115]$. Moreover, this group was again followed after 23 years and showed decreased prevalence of cardiovascular diseases [116].

As obesity is a potent risk factor of DM and dementia, Brazil government has implemented various health policies time to time. In 1999, they took initiative by preventive and management programs for obesity for all the social groups and also developed the nationwide and interdepartmental programs [117]. The public policy structures focused on dietary and nutritional education (2012). In addition, the aim of Ministry of Health was the development of various academies for physical and health-promoting activities for the encouragement of physical activity. Brazil also promotes social participation and has developed variety of councils in multiple regions of the government, for example, The National Health Council (CNS) and the National Food and Nutritional Security Council [117].

Sri Lanka is also one of the main nations in SEA which is combating DM aggressively. There are various programs in Sri Lanka to manage, control, and create awareness about DM. They have launched various programs funded by different organizations and charitable trusts with the aim of spreading awareness about DM and the comorbidities associated with it among the community. Moreover, media has also played imperative role along with healthcare professionals for success of these national programs [118].

\section{Indian Preventive Initiatives}

India is home to huge number of diabetic patients in the world and will soon become the nation having maximum number of diabetic patients in the world. Therefore, to eradicate the problem of diabetes, Government of India has taken up various steps. The PMO has initiated the "fit India" program. Ministry of Health and Family Welfare started a National Programme for Prevention and Control of Diabetes, Cardiovascular Disease and Stroke in 10 districts of 10 states of India in 2008. The main logo in this scheme was "fitness is essential for survival". National Programme for Prevention and Control of Diabetes, Cardiovascular Disease and Stroke through this program made provision of supplying free diagnostics and free drugs for NCD patients visiting 388 district NCD clinics and 2,115 community health centers NCD clinics across India (till March 2017) [119]. Under the same scheme, Odisha state government supplied free anti-diabetic drugs and insulin to patients at government health centers. The state government subsequently increased annual drug budget of Rs 200 million for purchasing the medicines. The core objective for this programme was promotion of health among the community to understand the occurrence of high-risk individuals and prevention of disease. Hence, for the achievement of this objective, various methods were used like activities in school, workplace, and general population. Further, for risk analysis, screening, monitoring, and research programs were encouraged. Moreover, health workers were also motivated to perform their duty in the welfare of society and provide necessary information in the community to help them develop healthy habits and managing their health. By using simple community health methods, the risk for diseases like diabetes, cardiovascular diseases, and stroke was significantly decreased.

\section{Ayushman Bharat}

This is world's largest government-funded health insurance scheme that has been implemented to provide free essential diagnostics and treatment for non-communicable disorders with possible involvement of corporate social responsibility. This will have 2 components, namely, Health wellness and the National Health Protection to be provisioned through 150,000 wellness centers.

\section{Initiatives for Ayushman Bharat}

Yoga as an Alternative Intervention

According to world morbidity statistics, NCDs prevention and control are the major targets of universal health coverage. Cognitive dysfunction and dementia have been neglected as a complication of DM [120]. DM and dementia, being age-related disorders, are a major public health concern with its cost implication, thus indicating preventive, curative, and cost-effective measures should be required. There are several drugs to either provide temporary relief or control for the chronic diseases like DM and dementia, AD, cancers and stroke, and age-related macular degeneration (AMD). However, most of them have no permanent remedy. A wealth of resources have been invested in developing new drugs, but a good number of them have no clinical benefits and some even have adverse effects with overburdening cost implications.

Therefore, with burgeoning population and escalating health costs for the management of diabetes and associated dementia, a pragmatic cost-effective integrated approach of wellness and Yogic intervention is necessary. 


\section{Need for the Electronic Health Records}

From ancient times, Yoga has been incorporated into cultural and physical activity and used for balancing emotional, physical, and spiritual health. In the growing era of modern medicine, evidence from clinical research is required to integrate various approaches in health care. Studies have shown Yoga effectiveness in symptomatic relief and improving patient outcomes in chronic diseases. Despite increased number of Yoga studies and substantial benefits in many NCDs, it remains unclear if the existing studies depicting beneficial aspect of Yoga can be applicable to other population, cultures, and religions. The underlying mechanisms behind the observed benefits still need to be clearly understood. Furthermore, costeffectiveness studies and long follow-up studies need to be conducted. Electronic Health Records (EHR) consist of computerized healthcare system to store electronic health information including life events, medications, vitals, past medical history, laboratory data, and radiographs. This transformation has not only improved clinical outcome of individual patients but also created a scope for improving population health by conducting research. When clinical data are stored electronically that can be pooled for its quantitative analysis and better understanding of disease prognosis, diagnosis, treatment, and costs can be drastically reduced [121]. Implementing EHRs into Ayushman Bharat can potentially grow pool of clinical and biochemical data of patients with NCDs and the effect of Yoga intervention that can be internally assessed to analyze its comparative effectiveness and costeffectiveness [122]. Further efficacy studies for Yoga from the pooled data will increase body of evidence for Yoga effectiveness on NCDs. Thus, Yoga can be widely advocated as a cost-effective non-pharmacological intervention and can be institutionalized in synchronization, cooperation, and collaboration with modern medicine by using EHRs.

\section{EHRs and Opportunity of Research Trials}

Researchers from India have been importing kits for many NCDs, yet there is an increased inflow of this equipment from the foreign countries. Due to insufficient patient data and research, India is not sufficiently able to generate adequate evidence. After the introduction of EHRs as a part of Ayushman Bharat, many biochemical kits can be developed in India. These could come to existence with wealth of patient data retrievable

Yoga for Lifestyle Disorders and accessible from EHRs. This may also reduce the dependence of India on importing kits of many NCDs from foreign countries.

\section{Insurance Policies for Major NCDs and Alternative Medicine}

In the context of ever-rising healthcare costs, the importance of health insurance is enormous. Very few insurance schemes cover preexisting diseases including $\mathrm{DM}$, dementia, cancer, hypertension, and asthma, and people who suffer remain deprived of comprehensive health coverage. It would be helpful if the recently launched Ayushman Bharat Health Insurance scheme caters to preexisting conditions like diabetes and dementia through cost-effective alternative therapies like Yoga [123], thereby preventing conversion of pre-diabetes into diabetes, mild cognitive impairment to $\mathrm{AD}$, TIA into stroke, dry AMD into wet AMD, and even precancers into full-blown cancer by mere Yoga-based lifestyle change. The integration of both traditional and modern approaches can be positioned at an insurance premium across all districts in India through Ayushman Bharat.

\section{Conclusion}

$\mathrm{DM}$ is a metabolic disorder that is not treatable and can only be managed using some drugs. However, such treatment is not without side-effects. The high-risk individual can be screened by utilizing an Indian Diabetic Risk Score [124] based questionnaire that can be administered in a population level. A preliminary intervention is possible at the community level. It will be useful to halt the onset of diabetes and associated dementia by Yoga intervention. The modification of lifestyle factors such as dietary changes as well as physical inactivity through Yoga intervention can be a cost-effective approach in managing diabetes and associated dementia. India can play a lead role in leveraging Yoga technology in SEA through its recently standardized Diabetic Yoga Protocols and Level 1 and Level II accreditation programs for Yoga professionals. With such centers, the long-term studies examining the longitudinal effects of Yoga interventions among diabetics and dementia can also be launched.

\section{Acknowledgment}

Not applicable. 


\section{Disclosure Statement}

The authors have no conflict of interest.

\section{Funding Sources}

There is no funding sources to declare.

\section{Author Contributions}

P.B.: literature search, collection, manuscript writing. N.K.: writing, table compilation, literature search. A.T.: writing, collection literature search. S.B.: schematic. V.P., S.K., and A.G.: writing a section. C.D.: writing a section, table compilation. M.S.S.: writing multiple sections, table compilation, submission. S.M.: writing a section, editing. N.M.: co-conceptualization. A.A.: manuscript writing, conceptualization and editing.

\section{References}

1 Joshi SR. Diabetes Care in India. Ann Glob Health. 2015 Nov-Dec;81(6):830-8.

2 Pai LW, Chang PY, Chen W, Hwu YJ, Lai CH. The effectiveness of physical leisure time activities on glycaemic control in adult patients with diabetes type 2: A Systematic Review. JBI Library Syst Rev. 2012;10(42 Suppl):1-20.

3 Tuomilehto J, Lindström J, Eriksson JG, Valle TT, Hämäläinen H, Ilanne-Parikka P, et al.; Finnish Diabetes Prevention Study Group. Prevention of type 2 diabetes mellitus by changes in lifestyle among subjects with impaired glucose tolerance. N Engl J Med. 2001 May;344(18):1343-50.

4 Chiodini I, Adda G, Scillitani A, Coletti F, Morelli V, Di Lembo S, et al. Cortisol secretion in patients with type 2 diabetes: relationship with chronic complications. Diabetes Care. 2007 Jan;30(1):83-8.

5 Tsugawa A, Ogawa Y, Takenoshita N, Kaneko Y, Hatanaka H, Jaime E, et al. Decreased muscle strength and quality in diabetes-related dementia. Dement Geriatr Cogn Disord Extra. 2017 Dec;7(3):454-62.

6 Meloni M, Izzo V, Giurato L, Uccioli L. A Complication of the Complications: The Complexity of Pathogenesis and the Role of Co-Morbidities in the Diabetic Foot Syndrome. The Diabetic Foot Syndrome. 26. Karger Publishers; 2018. pp. 19-32.

7 Vizcaino M, Stover E. The effect of yoga practice on glycemic control and other health parameters in Type 2 diabetes mellitus patients: A systematic review and meta-analysis. Complement Ther Med. 2016 Oct;28:57-66.

8 Zhu Y, Zhang C. Prevalence of gestational diabetes and risk of progression to type 2 diabetes: a global perspective. Curr Diab Rep. 2016 Jan;16(1):7.

9 India IFo. International Federation of India South East Asia. [August 09, 2019]. Available from: https://idf.org/our-network/regions-members/south-east-asia/ members/94-india.html

10 Akhtar SN, Dhillon P. Prevalence of diagnosed diabetes and associated risk factors: evidence from the large-scale surveys in India. J Soc Health Diabetes. 2017;5(1):28.

11 United Nations DoE. Social Affairs PD. World Population Ageing 2015 (ST/ESA/SER. A/390). NY: United Nations New York; 2015.
12 Nichols E, Szoeke CE, Vollset SE, Abbasi N, Abd-Allah F, Abdela J, et al.; GBD 2016 Dementia Collaborators. Global, regional, and national burden of Alzheimer's disease and other dementias, 1990-2016: a systematic analysis for the Global Burden of Disease Study 2016. Lancet Neurol. 2019 Jan;18(1): 88-106.

13 Das SK, Pal S, Ghosal MK. Dementia: indian scenario. Neurol India. 2012 Nov-Dec;60(6): 618-24.

14 Akter K, Lanza EA, Martin SA, Myronyuk N, Rua M, Raffa RB. Diabetes mellitus and Alzheimer's disease: shared pathology and treatment? Br J Clin Pharmacol. 2011 Mar;71(3): 365-76.

15 Zheng F, Yan L, Yang Z, Zhong B, Xie W. HbAlc, diabetes and cognitive decline: the English Longitudinal Study of Ageing. Diabetologia. 2018 Apr;61(4):839-48.

16 Hassing LB, Grant MD, Hofer SM, Pedersen NL, Nilsson SE, Berg S, et al. Type 2 diabetes mellitus contributes to cognitive decline in old age: a longitudinal population-based study. J Int Neuropsychol Soc. 2004 Jul;10(4):599-607.

17 Gregg EW, Yaffe K, Cauley JA, Rolka DB, Blackwell TL, Narayan KM, et al. Is diabetes associated with cognitive impairment and cognitive decline among older women? Study of Osteoporotic Fractures Research Group. Arch Intern Med. 2000 Jan;160(2):174-80.

18 Stewart R, Liolitsa D. Type 2 diabetes mellitus, cognitive impairment and dementia. Diabet Med. 1999 Feb;16(2):93-112.

19 Raina SK, Chander V, Raina S, Kumar D, Grover A, Bhardwaj A. Hypertension and diabetes as risk factors for dementia: A secondary post-hoc analysis from north-west India. Ann Indian Acad Neurol. 2015 Jan-Mar; 18(1):63-5.

20 Singh-Manoux A, Dugravot A, Shipley M, Brunner EJ, Elbaz A, Sabia S, et al. Obesity trajectories and risk of dementia: 28 years of follow-up in the Whitehall II Study. Alzheimers Dement. 2018 Feb;14(2):178-86.

21 Solanki RK, Dubey V, Munshi D. Neurocognitive impairment and comorbid depression in patients of diabetes mellitus. Int J Diabetes Dev Ctries. 2009 Jul;29(3):133-8.

22 Kota LN, Shankarappa BM, Shivakumar P, Sadanand S, Bagepally BS, Krishnappa SB, et al. Dementia and diabetes mellitus: association with apolipoprotein e4 polymorphism from a hospital in southern India. Int $\mathrm{J} \mathrm{Al}$ zheimers Dis. 2012;2012:702972.

23 Khattar D, Khaliq F, Vaney N, Madhu SV. Is Metformin-Induced Vitamin B12 Deficiency Responsible for Cognitive Decline in Type 2 Diabetes? Indian J Psychol Med. 2016 JulAug;38(4):285-90.

24 Pal DK, Bhalla A, Bammidi S, Telles S, Kohli A, Kumar S, et al. Can Yoga-Based Diabetes Management Studies Facilitate Integrative Medicine in India Current Status and Future Directions. Integr Med Int. 2017;4(3-4):12541.

25 Logroscino G, Kang JH, Grodstein F. Prospective study of type 2 diabetes and cognitive decline in women aged 70-81 years. BMJ. 2004 Mar;328(7439):548.

26 Herath PM, Cherbuin N, Eramudugolla R, Anstey KJ. The effect of diabetes medication on cognitive function: evidence from the PATH Through Life study. Biomed Res Int. 2016;2016:7208429.

27 Ng TP, Feng L, Yap KB, Lee TS, Tan CH, Winblad B. Long-term metformin usage and cognitive function among older adults with diabetes. J Alzheimers Dis. 2014;41(1):61-8.

28 Group DP; Diabetes Prevention Program Research Group. Long-term safety, tolerability, and weight loss associated with metformin in the Diabetes Prevention Program Outcomes Study. Diabetes Care. 2012 Apr;35(4):731-7.

29 Ridley NJ, Draper B, Withall A. Alcohol-related dementia: an update of the evidence. Alzheimers Res Ther. 2013 Jan;5(1):3.

30 Ravikumar P, Bhansali A, Ravikiran M, Bhansali S, Walia R, Shanmugasundar G, et al. Prevalence and risk factors of diabetes in a community-based study in North India: the Chandigarh Urban Diabetes Study (CUDS). Diabetes Metab. 2011 Jun;37(3):216-21.

31 Luchsinger JA, Tang MX, Siddiqui M, Shea S, Mayeux R. Alcohol intake and risk of dementia. J Am Geriatr Soc. 2004 Apr;52(4):540-6.

32 Ahmed SJ, Siddique MA, Barua A, Saikia H. Risk factors of diabetes mellitus amongst the executives of an industrial area of North East India: A community based cross sectional study. Diabetes Metab Syndr. 2017 Nov;11 Suppl 1:S87-90. 
33 Clegg A, Bryant J, Nicholson T, McIntyre L, De Broe S, Gerard K, et al. Clinical and costeffectiveness of donepezil, rivastigmine, and galantamine for Alzheimer's disease. A systematic review. Int J Technol Assess Health Care. 2002;18(3):497-507.

34 Marín-Peñalver JJ, Martín-Timón I, Sevillano-Collantes C, Del Cañizo-Gómez FJ. Update on the treatment of type 2 diabetes mellitus. World J Diabetes. 2016 Sep;7(17):354-95.

35 Anjana RM, Pradeepa R, Deepa M, Datta M, Sudha V, Unnikrishnan R, et al.; ICMR-INDIAB Collaborative Study Group. Prevalence of diabetes and prediabetes (impaired fasting glucose and/or impaired glucose tolerance) in urban and rural India: phase I results of the Indian Council of Medical Research-INdia DIABetes (ICMR-INDIAB) study. Diabetologia. 2011 Dec;54(12):3022-7.

36 Yoon KH, Lee JH, Kim JW, Cho JH, Choi YH, $\mathrm{Ko} \mathrm{SH}$, et al. Epidemic obesity and type 2 diabetes in Asia. Lancet. 2006 Nov;368(9548): $1681-8$.

37 Ramachandran A, Mary S, Yamuna A, Murugesan N, Snehalatha C. High prevalence of diabetes and cardiovascular risk factors associated with urbanization in India. Diabetes Care. 2008 May;31(5):893-8.

38 Ramachandran A, Ma RC, Snehalatha C. Diabetes in Asia. Lancet. 2010 Jan;375(9712): 408-18.

39 Podcasy JL, Epperson CN. Considering sex and gender in Alzheimer disease and other dementias. Dialogues Clin Neurosci. 2016 Dec;18(4):437-46.

40 Whalley LJ, Staff RT, Murray AD, Deary IJ, Starr JM. Genetic and environmental factors in late onset dementia: possible role for early parental death. Int J Geriatr Psychiatry. 2013 Jan;28(1):75-81.

41 Shantakumari N, Sequeira S, El deeb R. Effects of a yoga intervention on lipid profiles of diabetes patients with dyslipidemia. Indian Heart J. 2013 Mar-Apr;65(2):127-31.

42 Vijayakumar G, Sreehari GK, Vijayakumar A, Jaleel A. Distinct Predictors and Comorbidities in Early Onset Type 2 Diabetes Mellitus Among Asian Indians. Metab Syndr Relat Disord. 2017 Nov; 15(9):458-64.

43 Unnikrishnan R, Anjana RM, Amutha A, Ranjani H, Jebarani S, Ali MK, et al. Youngeronset versus older-onset type 2 diabetes: clinical profile and complications. I Diabetes Complications. 2017 Jun;31(6):971-5.

44 Lindsay J, Laurin D, Verreault R, Hébert R, Helliwell B, Hill GB, et al. Risk factors for Alzheimer's disease: a prospective analysis from the Canadian Study of Health and Aging. Am J Epidemiol. 2002 Sep;156(5):445-53.

45 LoGiudice D, Watson R. Dementia in older people: an update. Intern Med J. 2014 Nov; 44(11):1066-73.

46 Walsh DM, Selkoe DJ. Deciphering the molecular basis of memory failure in Alzheimer's disease. Neuron. 2004 Sep;44(1):181-93.

47 Fratiglioni L. Epidemiology of Alzheimer's disease and current possibilities for preven- tion. Acta Neurol Scand Suppl. 1996;165:3340.

48 Rawlings AM, Sharrett AR, Mosley TH, Ballew SH, Deal JA, Selvin E. Glucose Peaks and the Risk of Dementia and 20-Year Cognitive Decline. Diabetes Care. 2017 Jul;40(7): 879-86.

49 Huang J, Schmeidler J, Beeri MS, Rosendorff C, Bhatia S, West RK, et al. Haemoglobin $A(1 c)$ and cognitive function in very old, cognitively intact men. Age Ageing. 2012 Jan; 41(1):125-8.

50 Koppes LLJ, Dekker JM, Hendriks HFJ, Bouter LM, Heine RJ. Moderate Alcohol Consumption Lowers the Risk of Type 2 Diabetes: A meta-analysis of prospective observational studies. Diabetes Care. 2005 Mar;28(3):71925.

51 Huang J, Wang X, Zhang Y. Specific types of alcoholic beverage consumption and risk of type 2 diabetes: A systematic review and meta-analysis. J Diabetes Investig. 2017 Jan;8(1): 56-68.

52 Harper C. The neuropathology of alcohol-related brain damage. Alcohol Alcohol. 2009 Mar-Apr;44(2):136-40.

53 Launer LJ, Andersen K, Dewey ME, Letenneur L, Ott A, Amaducci LA, et al. Rates and risk factors for dementia and Alzheimer's disease: results from EURODEM pooled analyses. EURODEM Incidence Research Group and Work Groups. European Studies of Dementia. Neurology. 1999 Jan;52(1):78-84.

54 Hebert LE, Scherr PA, Beckett LA, Funkenstein HH, Albert MS, Chown MJ, et al. Relation of smoking and alcohol consumption to incident Alzheimer's disease. Am J Epidemiol. 1992 Feb;135(4):347-55.

55 Doll R, Peto R, Boreham J, Sutherland I. Smoking and dementia in male British doctors: prospective study. BMJ. 2000 Apr;320(7242): 1097-102.

56 Nilsson PM, Nilsson JA, Berglund G. Population-attributable risk of coronary heart disease risk factors during long-term follow-up: the Malmö Preventive Project. J Intern Med. 2006 Aug;260(2):134-41

57 Luchsinger JA, Reitz C, Honig LS, Tang MX, Shea S, Mayeux R. Aggregation of vascular risk factors and risk of incident Alzheimer disease. Neurology. 2005 Aug;65(4):545-51.

58 Beeri MS, Rapp M, Silverman JM, Schmeidler J, Grossman HT, Fallon JT, et al. Coronary artery disease is associated with Alzheimer disease neuropathology in APOE4 carriers. Neurology. 2006 May;66(9):1399-404.

59 Ott A, Slooter AJ, Hofman A, van Harskamp F, Witteman JC, Van Broeckhoven C, et al. Smoking and risk of dementia and Alzheimer's disease in a population-based cohort study: the Rotterdam Study. Lancet. 1998 Jun; 351(9119):1840-3.

60 Anstey KJ, von Sanden C, Salim A, O'Kearney R. Smoking as a risk factor for dementia and cognitive decline: a meta-analysis of prospective studies. Am J Epidemiol. 2007 Aug; 166(4):367-78.
61 Chen JH, Lin KP, Chen YC. Risk factors for dementia. J Formos Med Assoc. 2009 Oct; 108(10):754-64.

62 Anstey KJ, Cherbuin N, Budge M, Young J. Body mass index in midlife and late-life as a risk factor for dementia: a meta-analysis of prospective studies. Obes Rev. 2011 May; 12(5):e426-37.

63 Matioli MN, Suemoto CK, Rodriguez RD, Farias DS, da Silva MM, Leite RE, et al. Association between diabetes and causes of dementia: evidence from a clinicopathological study. Dement Neuropsychol. 2017 Oct-Dec; 11(4):406-12.

64 Bays HE, Chapman RH, Grandy S; SHIELD Investigators' Group. The relationship of body mass index to diabetes mellitus, hypertension and dyslipidaemia: comparison of data from two national surveys. Int J Clin Pract. 2007 May;61(5):737-47.

65 Weaver LJ, Worthman CM, DeCaro JA, Madhu SV. The signs of stress: embodiments of biosocial stress among type 2 diabetic women in New Delhi, India. Soc Sci Med. 2015 Apr; 131:122-30.

66 Wang KC, Woung LC, Tsai MT, Liu CC, Su YH, Li CY. Risk of Alzheimer's disease in relation to diabetes: a population-based cohort study. Neuroepidemiology. 2012;38(4):23744.

67 Andersen K, Launer LJ, Dewey ME, Letenneur L, Ott A, Copeland JR, et al.; EURODEM Incidence Research Group. Gender differences in the incidence of AD and vascular dementia: the EURODEM Studies. Neurology. 1999 Dec;53(9):1992-7.

68 Agrawal S, Ebrahim S. Prevalence and risk factors for self-reported diabetes among adult men and women in India: findings from a national cross-sectional survey. Public Health Nutr. 2012 Jun;15(6):1065-77.

69 Agrawal S, Ebrahim S. Association between legume intake and self-reported diabetes among adult men and women in India. BMC Public Health. 2013 Aug;13(1):706.

70 Solfrizzi V, Panza F, Capurso A. The role of diet in cognitive decline. J Neural Transm (Vienna). 2003 Jan;110(1):95-110.

71 Panza F, Solfrizzi V, Colacicco AM, D'Introno A, Capurso C, Torres F, et al. Mediterranean diet and cognitive decline. Public Health Nutr. 2004 Oct;7(7):959-63.

72 Götz J, Ittner LM, Lim YA. Common features between diabetes mellitus and Alzheimer's disease. Cell Mol Life Sci. 2009 Apr;66(8):1321-5.

73 Zhang W, Xin L, Lu Y. Integrative Analysis to Identify Common Genetic Markers of Metabolic Syndrome, Dementia, and Diabetes. Med Sci Monit. 2017 Dec;23:5885-91.

74 Casey DA, Antimisiaris D, O’Brien J. Drugs for Alzheimer's disease: are they effective? $\mathrm{P}$ T. 2010 Apr;35(4):208-11.

75 George MM, Copeland KC. Current treatment options for type 2 diabetes mellitus in youth: today's realities and lessons from the TODAY study. Curr Diab Rep. 2013 Feb; 13(1):72-80. 
76 Baycrest. Comprehensive Care Transition: A Trial of an Enhanced Care Transition Process in Dementia. ClinicalTrialsgov Identifier: NCT02415504. 2015.

77 S. P. Treatment of Elderly Subjects With Psychosis and Behavioral Disturbances Associated With Dementia of the Alzheimer's Type. ClinicalTrialsgov Identifier: NCT00160147. 2005.

78 S P. Treatment of Elderly Subjects With Psychosis and Behavioral Disturbances Associated With Dementia of the Alzheimer's Type. ClinicalTrialsgov Identifier: NCT00160147. 2008.

$79 \mathrm{~A} / \mathrm{S}$ NN. A Trial Investigating the Efficacy and Safety of Insulin Detemir Versus Insulin NPH in Combination With Metformin and Diet/Exercise in Children and Adolescents With Type 2 Diabetes Insufficiently Controlled on Metformin With or Without Other Oral Antidiabetic Drug(s) With or Without Basal Insulin (iDEAt2). 2017.

80 Sanofi. A Glycemic Control Evaluation of Glimepiride Versus Rimonabant on Top of Metformin in Type 2 Diabetes (ALLEGRO). ClinicalTrialsgov Identifier: NCT00449605. 2016.

81 R. S. Study to Evaluate the Effect of Megestrol Acetate in Weight Loss in Dementia Patients. clinicaltrialsgov. 2007.

82 Novartis. Aliskiren Trial in Type 2 Diabetes Using Cardiovascular and Renal Disease Endpoints (Core and Extension Phases) (ALTITUDE). ClinicalTrialsgov Identifier: NCT00549757. 2017.

83 Punthakee Z, Bosch J, Dagenais G, Diaz R, Holman R, Probstfield J, et al.; TIDE Trial Investigators. Design, history and results of the Thiazolidinedione Intervention with vitamin D Evaluation (TIDE) randomised controlled trial. Diabetologia. 2012 Jan;55(1) 36-45.

84 AstraZeneca. GALLANT 8 Tesaglitazar Addon to Metformin. ClinicalTrialsgov Identifier: NCT00251953. 2009.

85 Livingston G, Sommerlad A, Orgeta V, Costafreda SG, Huntley J, Ames D, et al. Dementia prevention, intervention, and care. Lancet. 2017 Dec;390(10113):2673-734.

86 Tari AR, Nauman J, Zisko N, Skjellegrind HK, Bosnes I, Bergh S, et al. Temporal changes in cardiorespiratory fitness and risk of dementia incidence and mortality: a population-based prospective cohort study. Lancet Public Health. 2019 Nov;4(11):e565-74.

87 Merino J, Florez JC. Precision medicine in diabetes: an opportunity for clinical translation. Ann N Y Acad Sci. 2018 Jan;1411(1) $140-52$.

88 Dendup T, Feng X, Clingan S, Astell-Burt T. Environmental Risk Factors for Developing Type 2 Diabetes Mellitus: A Systematic Review. Int J Environ Res Public Health. 2018 Jan;15(1):78.

89 Innes KE, Selfe TK. Yoga for adults with type 2 diabetes: a systematic review of controlled trials. J Diabetes Res. 2016;2016:6979370.
90 Mathersul DC, Rosenbaum S. The Roles of Exercise and Yoga in Ameliorating Depression as a Risk Factor for Cognitive Decline. Evid Based Complement Alternat Med. 2016;2016:4612953

91 Klarod K, Philippe M, Gatterer H, Burtscher M. Different training responses to eccentric endurance exercise at low and moderate altitudes in pre-diabetic men: a pilot study. Sport Sci Health. 2017;13(3):615-23.

92 Baker LD, Frank LL, Foster-Schubert K, Green PS, Wilkonson CW, Mctiernan A, et al. Effects of aerobic exercise on mild cognitive impairment: a controlled trial. Arch Neurol. 2010 Jan ;67(1):71-9.

93 Sharma NK, Robbins K, Wagner K, Colgrove YM. A randomized controlled pilot study of the therapeutic effects of yoga in people with Parkinson's disease. Int J Yoga. 2015 Jan;8(1): 74-9.

94 Kyizom T, Singh S, Singh KP, Tandon OP Kumar R. Effect of pranayama \& yoga-asana on cognitive brain functions in type 2 diabetes-P3 event related evoked potential (ERP). Indian J Med Res. 2010 May;131(5): 636-40.

95 Hariprasad VR, Koparde V, Sivakumar PT, Varambally S, Thirthalli J, Varghese M, et al. Randomized clinical trial of yoga-based intervention in residents from elderly homes: effects on cognitive function. Indian J Psychiatry. 2013 Jul;55(7 Suppl 3):S357-63.

96 Fan JT, Chen KM. Using silver yoga exercises to promote physical and mental health of elders with dementia in long-term care facilities. Int Psychogeriatr. 2011 Oct;23(8):122230.

97 Mooventhan A, Nivethitha L. Evidence based effects of yoga in neurological disorders. J Clin Neurosci. 2017 Sep;43:61-7.

98 Jayawardena R, Ranasinghe P, Chathuranga T, Atapattu PM, Misra A. The benefits of yoga practice compared to physical exercise in the management of type 2 Diabetes Mellitus: A systematic review and meta-analysis. Diabetes Metab Syndr. 2018 Sep;12(5):795-805.

99 Shohani M, Badfar G, Nasirkandy MP, Kaikhavani S, Rahmati S, Modmeli Y, et al. The effect of yoga on stress, anxiety, and depression in women. Int J Prev Med. 2018 Feb; 9(1):21.

100 Bernstein AM, Bar J, Ehrman JP, Golubic M, Roizen MF. Yoga in the management of overweight and obesity. Am J Lifestyle Med. 2014;8(1):33-41.

101 Singh S, Malhotra V, Singh KP, Sharma SB, Madhu SV, Tandon OP. A preliminary report on the role of yoga asanas on oxidative stress in non-insulin dependent diabetes mellitus. Indian J Clin Biochem. 2001 Jul;16(2):21620.

102 Mahapure HH, Shete SU, Bera TK. Effect of yogic exercise on super oxide dismutase levels in diabetics. Int J Yoga. 2008 Jan;1(1): 21-6.

103 Hegde SV, Adhikari P, Kotian S, Pinto VJ, D'Souza S, D'Souza V. Effect of 3-month yoga on oxidative stress in type 2 diabetes with or without complications: a controlled clinical trial. Diabetes Care. 2011 Oct;34(10): 2208-10.

104 Rajani SN, Indla YR, Archana R, Rajesh P. Role of yoga on cardic autonomic function tests and cognition in type 2 diabetes. Int Res Ayurveda Pharm. 2015 Nov-Dec;6(6): 764-6.

105 Deshpande S, Nagendra HR, Raghuram N. A randomized control trial of the effect of yoga on verbal aggressiveness in normal healthy volunteers. Int J Yoga. 2008 Jul;1(2):76-82.

106 Mondal S, Kundu B, Saha S. Yoga as a therapeutic intervention for the management of type 2 diabetes mellitus. Int J Yoga. 2018 May-Aug;11(2):129-38.

107 Sreedevi A, Gopalakrishnan UA, Karimassery Ramaiyer S, Kamalamma L. A Randomized controlled trial of the effect of yoga and peer support on glycaemic outcomes in women with type 2 diabetes mellitus: a feasibility study. BMC Complement Altern Med. 2017 Feb;17(1):100.

108 McDermott KA, Rao MR, Nagarathna R, Murphy EJ, Burke A, Nagendra RH, et al. A yoga intervention for type 2 diabetes risk reduction: a pilot randomized controlled trial. BMC Complement Altern Med. 2014 Jul; 14(1):212.

109 Singh AK, Kaur N, Kaushal S, Tyagi R, Mathur D, Sivapuram MS, et al. Partitioning of radiological, stress and biochemical changes in pre-diabetic women subjected to Diabetic Yoga Protocol. Diabetes Metab Syndr. 2019 Jul - Aug;13(4):2705-13.

110 Nagarathna R, Usharani M, Rao AR, Chaku R, Kulkarni R, Nagendra H. Efficacy of yoga based life style modification program on medication score and lipid profile in type 2 diabetes-a randomized control study. Int $\mathrm{J}$ Diabetes Dev Ctries. 2012;32(3):122-30.

111 Schoonover J, Lipkin S, Javid M, Rosen A, Solanki M, Shah S, et al. Perceptions of traditional healing for mental illness in rural Gujarat. Ann Glob Health. 2014 Mar-Apr; 80(2):96-102.

112 Tuck I, Johnson SC, Kuznetsova MI, McCrocklin C, Baxter M, Bennington LK. Sacred healing stories told at the end of life. J Holist Nurs. 2012 Jun;30(2):69-80.

113 Yin J, Kong AP, Chan JC. Prevention and care programs addressing the growing prevalence of diabetes in China. Curr Diab Rep. 2016 Dec;16(12):130.

114 Pan XR, Li GW, Hu YH, Wang JX, Yang WY, An ZX, et al. Effects of diet and exercise in preventing NIDDM in people with impaired glucose tolerance. The Da Qing IGT and Diabetes Study. Diabetes Care. 1997 Apr;20(4):537-44.

115 Li G, Zhang P, Wang J, Gregg EW, Yang W, Gong Q, et al. The long-term effect of lifestyle interventions to prevent diabetes in the China Da Qing Diabetes Prevention Study: a 20-year follow-up study. Lancet. 2008 May; 371(9626):1783-9. 
116 Li G, Zhang P, Wang J, An Y, Gong Q, Gregg EW, et al. Cardiovascular mortality, all-cause mortality, and diabetes incidence after lifestyle intervention for people with impaired glucose tolerance in the Da Qing Diabetes Prevention Study: a 23-year follow-up study. Lancet Diabetes Endocrinol. 2014 Jun;2(6): 474-80.

117 Jaime PC, da Silva ACF, Gentil PC, Claro R, Monteiro C. Brazilian obesity prevention and control initiatives. Obes Rev. 2013;14:88-95.

118 Gunathilake W, Kulasinghe R, Siriwardana A, Hettiarchchi K, Thomson G, Fernando D. En- gaging the media in diabetes prevention in Sri Lanka. Pract Diabetes Int. 2006;23(8):335-7.

119 Bhargava B, Paul VK. Informing NCD control efforts in India on the eve of Ayushman Bharat. Lancet. 2018, Epub ahead of print.

120 Kodl CT, Seaquist ER. Cognitive dysfunction and diabetes mellitus. Endocr Rev. 2008 Jun;29(4):494-511.

121 Menachemi N, Collum TH. Benefits and drawbacks of electronichealth record systems. Risk Manag Healthc Policy. 2011;4:47-55.

122 Ross A, Williams L, Pappas-Sandonas M, Touchton-Leonard K, Fogel D. Incorporat- ing yoga therapy into primary care: The Casey Health Institute. Int J Yoga Therap. 2015;25(1):43-9.

123 Aswathy S, Unnikrishnan AG, Kalra S. Effective management of type 2 DM in India: looking at low-cost adjunctive therapy. Indian J Endocrinol Metab. 2013 Jan;17(1): 149-52.

124 Mohan V, Deepa R, Deepa M, Somannavar S, Datta M. A simplified Indian Diabetes Risk Score for screening for undiagnosed diabetic subjects. J Assoc Physicians India. 2005 Sep;53:759-63. 